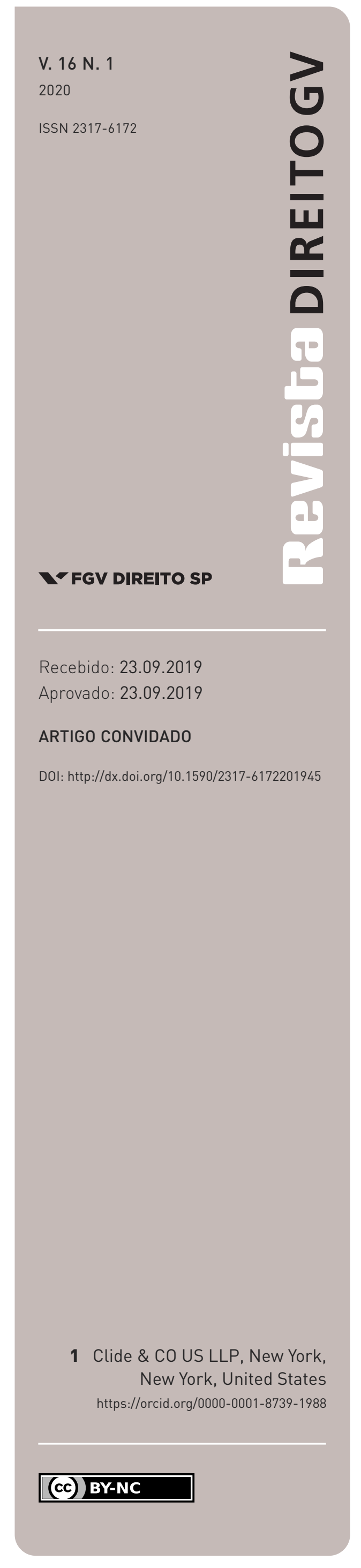

\title{
The Future of Law Firms (and Lawyers) in the Age of Artificial Intelligence
}

\author{
O FUTURO DOS ESCRITÓRIOS DE ADVOCACIA (E DOS ADVOGADOS) NA ERA DA \\ INTELIGÊNCIA ARTIFICIAL
}

\author{
Anthony E. Davis ${ }^{1}$
}

\begin{abstract}
This article explores the future for lawyers and law firms in the light of the changes that Artificial Intelligence ("Al") is already bringing to the universe of legal services. Part I briefly describes some of the ways Al is already in use in ordinary life - from facial recognition, through medical diagnosis to translation services. Part II describes how $\mathrm{Al}$ is transforming what it means to provide legal services in six primary areas: litigation review; expertise automation; legal research; contract analytics; contract and litigation document generation; and predictive analytics. Part III explores who are the providers of these Al driven legal services - often non-lawyer legal service providers - and how these providers are replacing at least some of what clients have traditionally sought from lawyers. Part III also discusses the implications of all these changes both for the future role of lawyers individually, and in particular what services will clients still need lawyers to perform: judgment, empathy, creativity and adaptability. In turn, this Part examines what will these changes mean for the size, shape, composition and economic model of law firms, as well as the implications of these changes for legal education and lawyer training. Part IV identifies the principal legal, ethical, regulatory and risk management issues raised by the use of $\mathrm{Al}$ in the provision of legal services. Finally, in Part V the article considers who will be the likely providers of Al based services other than law firms: legal publishers, major accounting firms and venture capital funded businesses.
\end{abstract}

\section{Keywords}

Artificial Intelligence (Al); Legal Service Providers; Lawyers; Law Firms; Future of Legal Services.

\section{Resumo}

Este artigo explora o futuro dos advogados e dos escritórios de advocacia à luz das mudanças que a Inteligência Artificial ("IA") já está trazendo para o universo dos serviços jurídicos. A Parte I descreve brevemente algumas das maneiras pelas quais a IA já está sendo usada na vida cotidiana, do reconhecimento facial, passando pelo diagnóstico médico, até os serviços de tradução. A Parte II descreve como a IA está transformando o que significa prestar serviços jurídicos em seis áreas principais: revisão de litígios; automação de expertise; pesquisa legal; análise de contrato; geração de documentos contratuais e contenciosos; e análise preditiva. A Parte III explora quem são os fornecedores desses serviços jurídicos orientados à IA geralmente prestadores de serviços jurídicos que não são advogados - e como esses prestadores estão substituindo pelo menos parte do que os clientes tradicionalmente procuram em advogados. A Parte III também discute as implicações de todas essas mudanças, tanto para o futuro papel dos advogados individualmente quanto particularmente para os serviços para os quais os clientes ainda precisarão de advogados: julgamento, empatia, criatividade e adaptabilidade. Por sua vez, essa parte examina o que essas mudanças significam para o tamanho, a forma, a composição e o modelo econômico dos escritórios de advocacia, bem como as implicações dessas mudanças na educação jurídica e no treinamento de advogados. A 
Parte IV identifica as principais questões jurídicas, éticas, regulatórias e de gerenciamento de riscos levantadas pelo uso da IA na prestação de serviços jurídicos. Por fim, na Parte $V$, considera-se quem serão os prováveis provedores de serviços baseados em IA que não sejam escritórios de advocacia: editores jurídicos, as principais empresas de contabilidade e negócios de capital de risco.

\section{Palavras-chave}

Inteligência Artificial (IA); prestadores de serviços jurídicos; advogados; escritórios de advocacia; futuro dos serviços jurídicos.

\section{INTRODUCTION}

Will law firms as we have known them still exist when our grandchildren are adults? This article is intended to initiate a discussion about the future for lawyers and law firms in the light of the extraordinary changes that Artificial Intelligence ("AI") is already bringing to the universe of legal services. The article is also intended as a precursor of a fuller treatment of all the topics raised; its focus is to identify the principal questions and issues that confront the profession as a result of the rise of AI.

The legal spend of corporations in the United States on traditional law firms remains flat, year after year, while the spend on in-house legal departments and on other legal service providers is exploding. More and more, both in-house counsel and these new legal service providers (and, to a limited extent, law firms) are using AI in ways that are transforming both what it means to provide legal advice and the ability of clients to manage - and control - the outside law firms to which they have traditionally turned for advice and representation. In Part I, this article will briefly describe what AI is, and the different ways it can be (and is being) applied to solve problems and provide solutions that benefit clients. Part II will review the different kinds of AI platforms that are already in use, or in late stage development, to provide substantive legal assistance to clients in ways that hitherto were the domain of large numbers of (principally younger) lawyers. Part III will consider how AI is likely to affect both the future role of lawyers and the implications of AI for the likely structure and composition of law firms. This part also examines how these changes will in turn affect law firms' hiring needs, the hiring models they will use, and the ways in which legal education, both pre- and post-admission, will have to change if law is to survive as a profession. Part IV will discuss the ethical, legal, regulatory and risk management issues that face law firms today when they introduce or provide AI platforms or solutions to their clients. Finally, Part V will consider whether other service providers, both professional and otherwise (including but not limited to developers of AI solutions), have economic and market place advantages that will enable them to replace lawyers and law firms. 


\section{Part i. What is Artificial Intelligence Anyway?}

\section{What Does IT Do?}

: It does (some of) the things we ask - e.g. Alexa

: It does facial recognition - you've read about the security uses and the privacy concerns

: It translates - e.g. Google Translate

: It does medical diagnoses (very accurately)

: It wins games - e.g. Go

\section{HOW DOES IT WORK?}

AI is all about inference of various kinds: logical, statistical and a combination of both. And in case you were wondering, statistical inference is based on very high level math ("automatically computing (and adjusting) the step size for gradient-based neural net training algorithms [by] estimating and tracking the largest eigenvalue of the Hessian matrix of a neural net's error surface”, Yann LeCun, 1993).

But it isn't necessary to understand the underlying math to be able to code, or teach software to learn skills. "If a typical person can do a mental task with less than one second of thought, we can probably automate it using AI either now or in the near future." Andrew $\mathrm{Ng}, 2016$

\section{WHY NOW?}

Between 2000 and 2017 three critical things happened simultaneously in the technology universe: computer processing power increased from $10^{3}$ to $10^{7}$; the cost of data storage reduced from $\$ 12.4$ per GB to $\$ 0.004$ per GB; and there was unquantifiable and astronomically huge data growth. In other words, we are now in an age when it's easy to harness computer power to engage in learning, it's cheap, and there are massive amounts of data from which to learn.

\section{Part 2. What Can AI Do in LaW - and What Is It Doing NOW}

In general, there are six ways that $\mathrm{AI}$ is being used in the legal arena:

: Document Discovery

: Expertise Automation

: Legal Research

: Document Management

: Contract and Litigation Document Analytics - and Contract and Litigation Document Generation

: Predictive Analytics 
What Dothey Do-And How Do They Affect the Delivery of Legal Services?

Document Discovery. This was the first use for AI in law and is quite well established. In essence, it is software that enables vast numbers of documents to be surveyed and those relevant to the search criteria identified at a fraction of the cost and in a fraction of the time, and generally much more accurately than when the same survey is performed by teams of lawyers or paralegals looking at computer screens.

Expertise Automation. This is, in essence, the commoditizing of legal knowledge that enables clients (as well as lawyers) to find answers to questions using the software developed for particular areas of legal information that once would have required interaction with a lawyer. Examples are software developed to enable individuals to draft a will, or companies to give access to their employees to answer common questions in a specific area such as employment law. For instance, a factory manager in a jurisdiction can ask the software what rights to family leave a pregnant employee has without the need to speak to a lawyer either within the company's legal department or its outside counsel. In addition, this is the realm of software increasingly developed to increase access to justice for individuals who do not have the resources to access a lawyer. These tools include will drafting, and even assist individuals in litigation contexts such as housing court or fighting traffic tickets.

Legal Research. Publishing companies have huge databases of knowledge of laws and regulations in multiple jurisdictions. They have developed software packages that enable clients (or lawyers) to do fast accurate (and therefore cheap) research that would have taken individual lawyers much longer (and more expensively, and probably less accurately) than was possible in earlier times. Some of them even have services that will do the work of answering questions using the software and providing the solutions directly to clients' legal departments without the intercession of an outside lawyer.

Document Management. Corporations often have thousands or tens of thousands of similar documents, such as contracts, that need to be managed for consistency and enforcement. An example was publicized by JP Morgan in 2017. The Bloomberg.com headline read: "JP Morgan Software Does in Seconds What Took Lawyers 360,000 Hours."

\section{Contract and Litigation Document Analytics - and Contract and Litigation} Document Generation. There are now numerous providers of AI tools to help lawyers draft consistent, appropriate and up-to-date documents, both in the transactional and litigation spheres, by reference to huge databases of precedents. In addition, there is a growing group of AI providers that offer what are essentially do-it-yourself tool kits to law firms and corporations to create their own analytics programs customized to their specific needs. 
Predictive Analytics. There are two main groups of AI tools that fit within this category. The first are the tools that will analyze all the decisions in a particular sphere, input the specific issues in a case, and provide a prediction of likely outcomes, including factors like the individual judge hearing the case. This is the group that the French have recently criminalized (a decision that seems about as likely to succeed in the long run as the early English king Canute, who stood at the sea shore and ordered the tide to turn). The other kind of analytics, of which there are now at least four available in the marketplace, will review a given piece of legal research, or legal submission to a court, and identify the key relevant precedents and authorities that are missing from the research or submission. In the United States one of these tools is available for free to judges, which raises the question whether it is now legal malpractice for lawyers not to use such a tool before filing legal papers with the court. Another use which is being made of this kind of software is by investment firms looking to analyze value and risk in businesses involved in litigation.

\section{Part 3. What Does the Advent ofThese Ai Solutions Mean for the Economics and Structure ofthe Legal Profession and the Training ofthe NeXT GeNerations OF LAWYers?}

The two fundamental questions presented by the arrival of these new tools are (i) who will provide the solutions to clients' problems and, as a subset of that question, what will be the role of lawyers in providing those solutions; and (ii) how will the answers to those questions affect the composition, structure and economics of law firms.

\section{Who Will Provide Clients With Legal Solutions?}

Thomson Reuters and the consultant Adam Smith, Esq. predicted in 2018 that in the United States the expenditures of corporations on legal solutions from both outside law firms and their internal legal departments will decline between 2017 and 2027, while the expenditure on alternative legal service providers (i.e. principally the providers of AI based solutions) will increase at least sevenfold (from an estimated $\$ 12$ billion in 2017 to $\$ 85$ billion in 2027). Another market research report issued in 2019 by Zion Market Research suggests that the global legal AI market will grow at 35.9\% per year/CAGR in terms of revenue between 2019 and 2026.

What does this mean for the role of individual lawyers in this new environment? Perhaps the best example of the most fundamental change is the report referred to earlier under the Document Management heading that JP Morgan in 2017 developed and used software to do in "Seconds What Took Lawyers 360,000 Hours." In other words, the drudge work traditionally done by starting out lawyers is already vanishing and will ultimately disappear almost entirely. And that holds true in all the realms in which AI is providing solutions, as described above, not just document management. However, contrary to the purveyors of gloom and 
doom about the future existence of the legal profession, lawyers will still have vital roles to perform - but they will be different and more refined than in the past.

Lawyers of the future will provide four basic kinds of service that AI cannot provide (and will not be able to provide unless and until "General Artificial Intelligence" becomes available at some point in the future). Those functions are: judgment; empathy; creativity and adaptability. In other words, lawyers will provide the last mile of solution delivery - the application of those human functions to the output of the AI tools. To take a simple example: suppose a predictive analytics tool tells the user that in a particular case, before an identified judge in a particular jurisdiction, the likelihood of a successful outcome is $60 \%$. But that prediction does not actually tell the lawyer or client what the client should actually do proceed or not. It will take a lawyer, using judgment to advise the client, using the lawyer's understanding of the client's needs (empathy), what path to choose.

\section{How Will This Change in Roles Affect the Composition, Structure and Economics of} LAW FIRMS?

This bundle of questions especially deserves extensive treatment. Here we can only give a brief summary of the likely implications of the impact of the changes being brought on (forced?) by the advent of AI solutions into legal services. The changes will be mostly focused in these areas: training and qualification of future generations of lawyers (and where that training will happen); the composition and structure of law firms; and the economics of law firms.

Lawyers of the future will not need to be able to "code;" but they will need an intimate and continuing understanding of how to identify and use AI solutions to meet their clients' needs. In particular, given that there is currently no rating system for the adequacy or effectiveness of individual AI solutions (see the following section on the ethical implications of AI derived legal service solutions), future lawyers will need to know how to be able to assess the relative strengths and weaknesses of particular solutions. Notably, the London based global firm Linklaters recently announced the creation of a special "track" for lawyers skilled in precisely this way. And O'Melveny \& Myers recently announced that in order to be considered for a summer associate position (the usual initial track for prospective associates at the firm) applicants would have to participate in an AI based online computer game designed, in essence, to test their team building (i.e. empathy) skills.

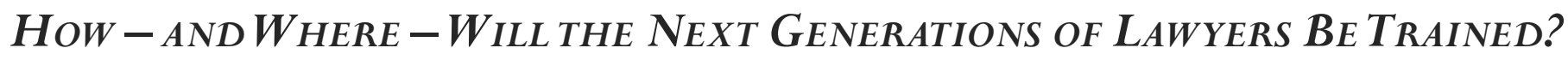

Where and when will lawyers receive the training they will need to survive and prosper in this new world? A small number of law schools are developing and offering a variety of technology training programs. But at least for now these programs reach only a tiny minority of law students. And then there is a second component to the problem faced both by individual lawyers and their firms. The ability to provide the critical "last mile" component of legal 
services - judgment. Future lawyers will need to develop those skills over time, imposing a rigorous training requirement on law firms that will continue over an extended period of time.

It inevitably follows that law firms will need to change their composition and structure in two critical ways. First, they will not need to recruit armies of young lawyers to perform services that are no longer needed, with the expectation that only a few will survive the first drudge filled years - in other words, the "old" model of hiring and then letting go large numbers of young lawyers cannot survive. Instead, because of the burdens of continuous training, firms will need to make much better hiring decisions, designed to identify the next generation of providers of the "last mile" services, with the particular goal that instead of these lawyers being a fungible and replaceable commodity, they will actually join the firm and stay with the firm over the long haul, in time becoming the judgment providers. And second they will need to develop a serious, long term program to train the next generation to become, over time, the judgment providers. In short, the future law firm - of whatever size and geographic reach - will need to be flat not a pyramid. While we make no predictions about which of the current generation of firms will be able to adapt in this way (and make the economic changes discussed below that are a necessary corollary of these structural changes), it seems likely that the firms of the future will be much more focused on specific practice expertise where they become the obvious providers of the "last mile" services in their chosen fields. It is hard to see how the "general service law firm" model of the past can survive the changes we envisage.

Perhaps most significant of all are the necessary economic and financial changes that will be required for law firms to prosper as the "last mile" providers. First, the billable hour, built on the back of the leverage system that made law firms so profitable in the past, will necessarily be replaced as the primary billing model. There is no way to make a profit out of charging for time spent when what the clients want and need are judgement, empathy, creativity and adaptability. And this inevitable change in the billing model is amplified by the structural changes described above - there will not be an army of associates whose time can be billed, rather there will be a cadre of next generation lawyers who are at least in part an expense component (in terms of the training requirements) rather than primary revenue and profit generators as in the past. In other words, the billing and overall profitability model for the successful law firm of the future will have to be defined in terms of the value clients place on the "last mile" services, having little or nothing to do with the time it takes for the lawyers involved to provide those services. To some extent these changes are already under way. Clients are already pushing back with ever greater force at paying for the time charges of young lawyers, and alternative fee arrangements are increasingly the norm.

There is a second component to the economic changes that will have to come into the law firm universe. While law firms persist, for whatever set of reasons, in being modeled on a partnership rather than a corporate structure, most if not all the profits necessarily get sucked out at the end of every financial year to pay the partners. In turn, this leaves very little 
reserved capital with which to invest in technology creation or in the other necessary structural changes described above. This problem is particularly acute in the United States, where the current byzantine regulatory structure is explicitly designed to prevent law firms from becoming partners with or accept investment from non-lawyers. On the other hand, the model of alternative business structures in place in England and Wales, and the similar changes previously adopted in Australia and now being developed in Canada, show the way for the future of the economic prosperity of law firms as part of a wider array of "legal service providers."

\section{Part 4.The Legal, Ethical, Regulatory and Risk Management Issues in the Provision of Legal Services Using AI}

Here again, in this article we can only highlight the principal issues that are associated with the use of AI solutions in the provision of legal services.

\section{The Duty of Competence}

The principal ethical obligation on lawyers when they are developing or assisting clients in identifying and using any AI solution is the duty of competence. The American Bar Association (ABA) recently explicitly included the obligation of "technological competence" as falling within the general duty of competence which exists within Rule 1.1 of its Model Rules of Professional Conduct ("Model Rules"), and many states have already followed suit within their own rules. (Also see the Australian Solicitors Conduct Rules 2012, Rule 4.1.3A.) The meaning and implications of "technological competence" goes beyond AI solutions (DAVIS and PUISZIS, 2019a and 2019b), but does have several specific implications for AI tools. One issue that is just beginning to be addressed in the literature, and to which even regulators are becoming aware, is the problem of built in bias and lack of transparency in the algorithms that underlie AI. Do particular solutions and products favor one group or disfavor others? Perhaps even more problematic is the fact that there is no independent analysis of the efficacy of any given AI solution, so that neither lawyers nor clients can easily determine which of several products or services actually achieve the results they promise, nor which is preferable for a given set of problems. Again, in the long run, it will be one of the tasks of the future lawyer to assist clients in making those determinations and selecting the most appropriate solution for a given problem. At a minimum, lawyers will need to be able to identify and access the expertise to make those judgments if they do not have it themselves.

\section{LEGAL LIABILITY WHEN AN AI SOLUTION FAILS}

In parallel to the ethical duty of competence are issues of legal liability in connection with the use of AI tools. Two particular liability issues are foremost. First, to what extent are or will lawyers be liable for whether, when and how they use - or fail to use - AI solutions to 
address client needs. One example explained above is whether a lawyer or law firm will be liable for malpractice if the judge in a matter accesses software that identifies governing or guiding principles or precedents that the lawyer failed to find or use. It does not seem to be a stretch to believe that liability should attach if the consequence of the lawyer's failure to use that kind of tool is a bad outcome for the client, and the client suffers injury as a result. Much more complex and difficult to resolve will be questions of the apportionment of liability as between the creator of a defective software solution and the law firm that uses it for the client's supposed benefit. Obviously, this will in part be decided by contract, but in the likely situation where the AI provider has a limitation of liability in its contract, what will happen to the lawyer's liability given that in some jurisdictions (including many states within the United Sates) the lawyer is not permitted to get an advance limitation of liability from the client? And even in determining relative liability as between the provider of the defective solution and the lawyer, what steps did the lawyer take to determine that the solution was the appropriate one for use in the particular client's matter?

\section{The Duty of Confidentiality}

A distinct and also vital ethical duty that lawyers will have to manage is to insure that the use of AI solutions does not pose a risk to the general duty to preserve client confidence and to maintain and preserve the attorney-client privilege.

\section{THE Duty to Supervise}

The ABA Model Rules and the rules in place in every American state establish an express and explicit duty to supervise subordinates, including third party providers, in connection with the delivery of legal services by the lawyer or law firm. (Also see the Australian Solicitors Conduct Rules 2012, Rule 37 Supervision of Legal Services.) Going back to the duty of competence, this supervisory duty assumes that lawyers are competent to select and oversee the proper use of AI solutions. Here again, this is not just a matter of the duty to supervise what goes on, and what tools are used within the law firm, but what third party provided tools are used, and how. Here also, the liability issues arise - did the law firm appropriately select the vendor, and did the lawyers manage the use of the solution.

\section{The Duty to Communicate}

In addition to the other duties already identified, lawyers have an explicit duty to communicate to their clients material matters in connection with the lawyers' services. This duty is set out in ABA Model Rule 1.4. (Also see the Australian Solicitors Conduct Rules 2012, Rule 7 Communication of Advice, and Rule 8 Client Instructions.) Thus, not only must lawyers be competent in the use of AI, but they will need to understand its use sufficiently to explain the question of the selection, use and supervision of AI tools. 


\section{REGULATORY ISSUES}

This article is not the place to discuss the role of the regulators of the legal profession in overseeing legal services being provided by non-lawyer alternative service providers. As we have seen, this is a rapidly expanding area of activity, to be contrasted with the likely contraction of traditional lawyer and law firm provided solutions. Some jurisdictions, such as England and Wales, as well as Australia, have already recognized, and others such as the Canadian provinces are in the process of adopting and implementing entity based regulation. This approach at least in part enables the regulators to oversee all the providers of legal services, and not simply traditional law firms. In the long run, this is going to be critically important in establishing appropriate standards to be complied with by all providers of AI based legal services. As mentioned above, addressing the issues of bias and transparency in AI tools, as well as advertising standards, will grow in importance as the use of AI itself grows. And clients in jurisdictions whose regulators are limited to overseeing only the services actually provided by lawyers are likely to suffer from the provision of AI solutions that are outside the scope and authority of the regulators to supervise. The significance and implications of this regulatory deficit or imbalance will become ever more pronounced as alternative legal service providers play an ever increasing role in providing clients with legal services without any direct involvement of lawyers.

\section{Part 5. Who Will Be the Providers of Ai Based Legal Services?}

As discussed above, the traditional economic model of partnership in law firms is essentially antithetical to the use of capital for the development of innovative technological solutions, with the exception of the very largest firms with the deepest pockets. Even there, it must be remembered that lawyers and law firms are not intrinsically risk takers. Of course, there are a number of law firms that have developed or are in the process of developing AI based solutions for particular applications to benefit their clients, where they have identified existing needs (so that the risk element is reduced). But the resources law firms have in the past can now or can be expected in the future to allocate to this process are minuscule in comparison with the billions - literally - of dollars being invested by non-law firm entrepreneurs and venture capitalists.

Three groups can be seen as predominating in the development of AI legal solutions. One, identified earlier, is the legal publishers - such as Thomson Reuters and Wolters Kluwer. A second group, always perceived as a direct threat by lawyers, is the major accounting firms. Both of these groups have two advantages over even the largest and most prestigious law firms: they are structured on a corporate and not a partnership model, so that they can accumulate and invest capital; and they have an expressed interest in penetrating the global market for legal services. And the third group is venture capital supported entrepreneurs within the high tech world. This group has hitherto been the source of the largest number and variety of 
AI solutions within all of the categories described in this article. Interestingly, there is already underway a consolidation among some of the early developers. Tens of merger and acquisition deals have already been announced in 2019 among the early players in this universe, evidently in order to obtain improved penetration into the market for these services based on greater capitalization. Notably, law firms have not been completely absent from this marketplace, in that there have been several joint ventures between traditional law firms and AI solution providers in recent months. Nevertheless, the relative inability and normal unwillingness to raise and apply risk capital leave law firms in last place as the originators of the solutions that are being or will be developed in the future. The future lies with those willing and able to place venture capital at risk. This is why the issue outlined in Part IV regarding the need for effective regulation of non-lawyer provided legal services is of critical importance to go forward.

\footnotetext{
ACKNOWLEDGEMENTS

I am deeply and greatly indebted to Michael Mills, the cofounder of Neota Logic and one of the leaders in the development of AI tools and solutions in the legal services arena, for large sections of the content, and many ideas that underlie and are expressed in this article. In addition, Bruce MacEwen of Adam Smith, Esq. has also been of great assistance in the material regarding the economics of both law firms and the alternative legal services industry.
}

\section{REFERENCES}

DAVIS, Anthony E.; PUISZIZ, Steven M. An Update on Lawyers' Duty of Technological Competence: Part I, New York Law Journal, March 1, 2019 a.

DAVIS, Anthony E.; PUISZIS, Steven M. An Update on Lawyers' Duty of Technological Competence: Part II, New York Law Journal, May 3, 2019b. 


\section{HOW TO QUOTE THIS ARTICLE:}

DAVIS, Anthony E. The Future of Law Firms (and Lawyers) in the Age of Artificial Intelligence. Revista Direito GV, v. 16, n. 1, Jan./Apr. 2020, e1945. doi: http://dx.doi.org/10.1590/23176172201945.

\section{Anthony E. Davis}

A laWyer's laWyer. LaWyer OF COUNSEL, Clide \& CO US LLP, BASED IN NEW YORK. HE ADVISES LAWYERS AND LAW FIRMS IN THE UNITED STATES AND INTERNATIONALLY IN THE AREAS OF PROFESSIONAL RESPONSIBILITY, RISK MANAGEMENT AND EVERY ASPECT OF THE LAW GOVERNING LAWYERS. CO-AUTHOR OF RISK MANAGEMENT: SURVIVAL TOOLS FOR LAW FIRMS, AMERICAN BAR ASSOCIATION ICO-PUBLISHED by the LaW Practice Management Section and the Center for

Professional Responsibility, $3^{\text {RD }}$ edition, With Katie M. LACHTER, 2015), AND AUTHOR OF NUMEROUS SCHOLARLY ARTICLES. LECTURER-IN-LAW AT COLUMBIA UNIVERSITY SCHOOL OF LAW, teACHING “Professional ResponsibiLity ISSUES IN BusinesS

Practice". He is a PASt President of the Association of Professional Responsibility LaWyers (APRL), a Fellow of the College of Law Practice Management, and a Member of the AMERICAN LAW INSTITUTE (ALI). HE RECEIVED HIS LAW DEGREE FROM CAMBridge University, AND AN LL.M. FROM NEW YoRK UNIVERSITY School of LaW. He is admitTed in NeW York, Colorado, and aS AN ENGLISH BARRISTER AND A SOLICITOR (BOTH NON-PRACTICING).

Anthony.Davisaclydeco.us 